\title{
Udeležba na izobraževanju "Better Training for Safer Food" v Münchnu, oktobra 2017
}

\section{Barbara PIŠKUR*}

Gozdarski inštitut Slovenije je s strani Uprave za varno hrano, veterinarstvo in zdravje rastlin Republike Slovenije (UVHVVR) pooblaščena organizacija, ki izvaja naloge zdravstvenega varstva rastlin v gozdarstvu. Zakon o zdravstvenem varstvu rastlin (ZZVR-1) določa pravila za zagotavljanje zdravja rastlin in zahteve $\mathrm{V}$ zvezi s preprečevanjem vnosa in širjenja ter zatiranjem škodljivih organizmov rastlin, ki lahko povzročijo tako ekonomske škode kot tudi negativno vplivajo na biotsko raznovrstnost. $Z$ rednim spremljanjem zdravstvenega stanja rastlin in načrtovanimi programi preiskav za ugotavljanje navzočnosti škodljivih organizmov lahko preprečimo ali zmanjšamo število izbruhov škodljivih organizmov in s tem zmanjšamo potencialne škode.

Evropska komisija je z Uredbo št. 652/2014 omogočila sofinanciranje izvajanje programov preiskav, kar kaže na pomembnost izvajanje le-teh na širšem evropskem območju. V Sloveniji programe preiskav škodljivih organizmov izvajajo nosilci javnih pooblastil ob koordinaciji UVHVVR.

Evropska komisija od leta 2006 izvaja programe delavnic "Better Training for Safer Food (BTSF)" s področja zakonodaje o hrani, zdravju živali in varstvu rastlin za boljšo usposobljenost pooblaščenih izvajalcev $\mathrm{v}$ evropskih in neevropskih državah, ki so odgovorni za kontrolo in izvajanje zakonodajnih zahtev.

V času od 23. do 26. oktobra 2017 je na Bavarskem potekala delavnica s področja izvajanja in priprave programov preiskav za ugotavljanje navzočnosti škodljivih organizmov rastlin. Poudarek delavnice je bil na implementaciji dobrih praks v izvedbo programov preiskav za karantenske škodljive organizme. Udeleženci smo se seznanili z veljavno zakonodajo Evropske unije s področja zdravstvenega varstva rastlin ter $\mathrm{z}$ mednarodnimi smernicami in priporočili. V sklopu štiridnevnih delavnic smo sodelovali pri simulacijah priprave programov preiskav ter se seznanili z izbruhi azijskega kozlička (Anoplophora glabripennis) na Bavarskem. Na Bavarskem so od leta 2004 odkrili šest izbruhov azijskega kozlička, od tega je en izbruh že izkoreninjen. Na terenu smo si ogledali karantensko območje v Feldkirchnu. Prva najdba azijskega kozlička je na tem območju bila 8.10.2012, okoli napadenih dreves so določili $100 \mathrm{~m}$ pas (napadeno območje; infested zone), kjer so odstranili vse gostiteljske rastline. Okoli napadenega območja so določili fokusno območje (focus zone; $500 \mathrm{~m}$ ) ter varovalni pas (buffer zone; $2100 \mathrm{~m}$ ). V fokusnem območju posebej izurjene plezalne ekipe pregledujejo gostiteljska drevesa, postavljene so feromonske pasti. V karantenskem območju Feldkirchen razmejeno območje obsega 3.129 ha, napadeno območje je veliko 111 ha. Od prve najdbe azijskega kozlička so podrli več kot 900 gostiteljskih dreves in 5 ha gozda. Podiranje in odstranjevanje napadenih dreves financira pristojna občina. Lastniki parcel v karantenskem območju so dolžni pregledovati gostiteljska drevesa vsaka dva meseca, dodaten nadzor opravljajo pooblaščene inštitucije. Občine v karantenskem območju takoj ob najdbi dobijo 100.000 EUR za hitro in učinkovito izvajanje ukrepov (Soforthilfe). Občine lahko dobijo dodatna sredstva, vendar le za namen sofinanciranja podiranja in odstranjevanja dreves na privatnih parcelah. Na delavnici so prikazali različne načine spremljanja območja, tudi s posebej izšolanimi psi, feromonskimi pastmi, z izšolanimi plezalnimi ekipami itd.

Delavnica BTSF v Münchnu je bila zanimiva, predvsem iz vidika kako programe preiskav izvajajo v drugih državah članicah EU ter kako so se ukrepanja ob najdbi karantenskega organizma lotili v nemški zvezni deželi Bavarski. Pri izvajanju programov preiskav ter izvedbi ukrepov prihaja do velikih birokratskih obremenitev, predvsem zaradi zahtev EU. Ravno tako je problem financiranje ukrepov in programov preiskav, saj EU ne krije vseh stroškov, ki ob tem nastanejo. Ukrepanje in izvajanje programov preiskav v gozdovih je v primerjavi s kmetijskimi površinami bolj kompleksno. 


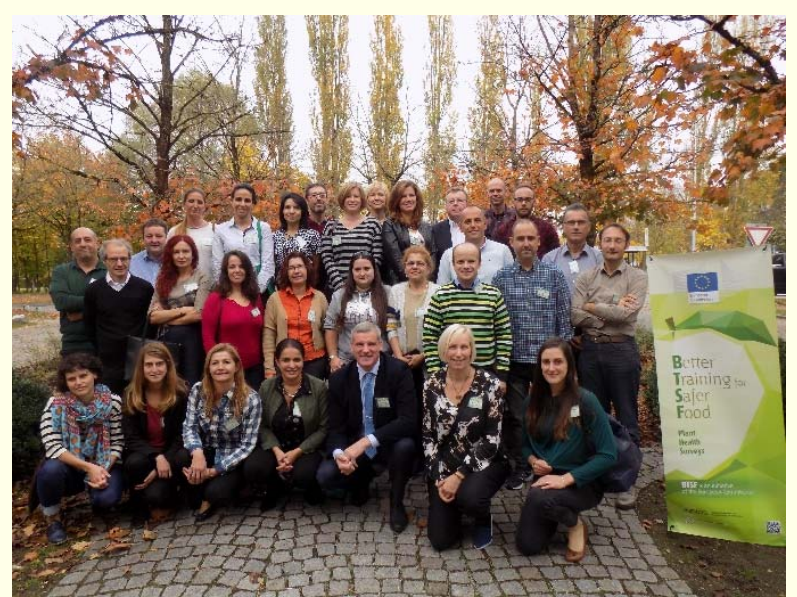

Slika 1. Skupinska slika udeležencev delavnice BTSF v Münchnu, ki je potekala od 23. do 26. oktobra 2017.

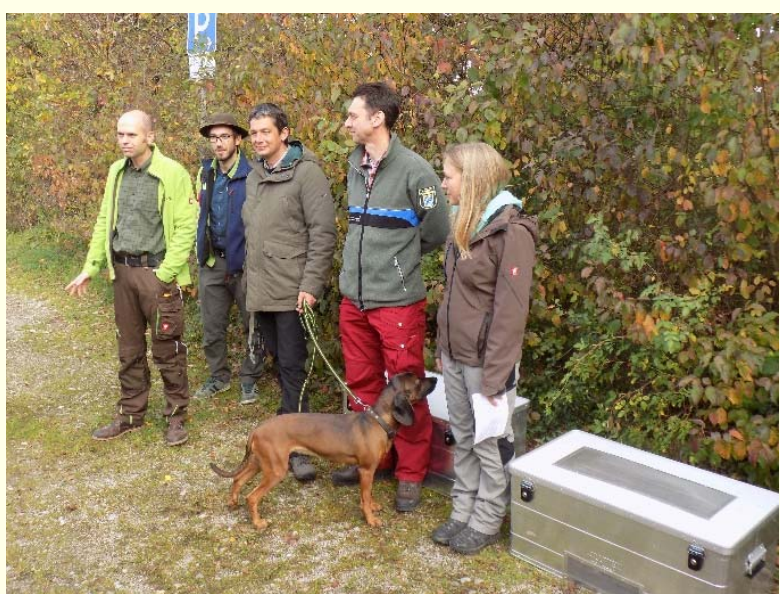

Slika 2. Napadena drevesa na Bavarskem iščejo s posebej izšolanimi psi za iskanje azijskih kozličkov.

${ }^{1}$ Gozdarski inštitut Slovenije, Večna pot 2, 1000 Ljubljana

"barbara.piskur@gozdis.si 